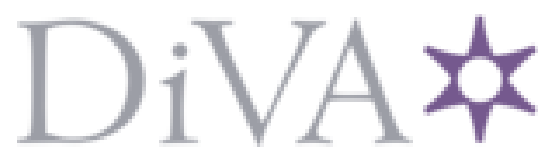

http://www.diva-portal.org

\title{
Postprint
}

This is the accepted version of a paper published in International Journal of Bank Marketing. This paper has been peer-reviewed but does not include the final publisher proof-corrections or journal pagination.

Citation for the original published paper (version of record):

Apanasevic, T., Markendahl, J., Arvidsson, N. (2016)

Stakeholders' expectations of mobile payment in retail: lessons from Sweden.

International Journal of Bank Marketing, 34(1): 37-61

http://dx.doi.org/10.1108/IJBM-06-2014-0064

Access to the published version may require subscription.

N.B. When citing this work, cite the original published paper.

Permanent link to this version:

http://urn.kb.se/resolve?urn=urn:nbn:se:kth:diva- 180577 


\section{Stakeholders ' expectations of mobile payment in retail: Lessons from Sweden}

Apanasevic, Tatjana, Wireless@KTH, KTH Royal Institute of Technology, Electrum 229, 16440, Kista, Sweden, tatjanaa@kth.se

Markendahl, Jan, Wireless@KTH, KTH Royal Institute of Technology, Electrum 229, 16440, Kista, Sweden, janmar@kth.se

Arvidsson, Niklas, Department of Industrial Economics and Management, KTH Royal Institute of Technology, Lindstedtsvägen 30, 10044, Stockholm, Sweden, niklas.arvidsson@indek.kth.se

\section{Abstract}

Purpose: The purpose of this paper is to explore the reasons behind the slow adoption of mobile payment services. The expectations of the main groups of stakeholders - the mobile service providers, the retailers, and the consumers - of the service in the retail industry in Sweden are examined.

Design/methodology/approach: The authors use a qualitative case study of stakeholders' expectations. The conceptual research framework is based on the theory of diffusion of innovations, the technology adoption model, and network externalities. The proposed framework was tested and validated by empirical findings.

Findings: One of the key findings of the research highlights that acceptance of a mobile payment service depends on the ability of mobile payment providers to build networks of both retailers and consumers simultaneously. The service will attract these stakeholders if it meets their expectations in the best possible way. Another finding is that mobile payment services do not meet expectations on an enhanced purchasing process. This is the area for future service improvement.

Research limitations/implications: The main limitation of this study is that only a few retailers were contacted.

Practical implications: First of all, criteria from the developed research framework can be used as a guide for mobile payment service development. Second, when developing and providing a mobile payment service, mobile payment providers need to have a good understanding of the needs and expectations of retailers and consumers.

Originality/value: Stakeholders' expectations have not been a focus for research in previous studies. This is a new research object.

\section{Introduction}

The level of mobile phone penetration in Europe is very high, and an average consumer has 1.2-1.3 mobile subscriptions (Ericsson, 2014). The rate of smartphone penetration continues to grow. The leaders are Norway, Sweden, the UK, and the Netherlands where the level of smartphone penetration is 'above or well above 60 percent' (Ericsson, 2014:2). As a consequence, the use of mobile services is constantly increasing. Specifically, consulting company Capgemini and The Royal Bank of Scotland forecast a significant growth for mobile payment services. The predicted global annual growth in the number of mobile payment transactions is expected to reach 60.8\% through 2015 (a total 47 billion transactions) (Capgemini and RBS, 2014). 
Mobile payments are payments which are implemented by using a mobile phone as a payment instrument for retailers. Mobile payments are expected to become the next step in the electronic payment evolution (Kim et al., 2010a). However, the European market for mobile payment services is in the early stage of adoption. Most of the services address specific needs (e.g. parking, vending machines, public transport ticketing) (Ondrus et al., 2009). In this context, different business actors have tried to introduce new mobile payment services for the retail industry in Sweden.

The mobile payment services used for payments at point of sale (POS) compete with cash and bank cards. Benefits for retailers include expectations of a lower transaction cost, faster service, and a decrease in the number of cash transactions (Mallat, 2007; Mallat and Tuunainen, 2008). The additional benefits of mobile payments for consumers are that purchases are independent from time and location, they are more convenient (Frolick and Chen, 2004; Constantiou et al., 2006; Mallat et al., 2009; Laukkanen and Kiviniemi, 2010), and they offer additional services such as person-to-person money transfers, ticketing, and loyalty programmes (Malat, 2007). However, despite the possible benefits of mobile payments, the rate of their adoption is lower than expected (Mallat, 2007). PostFinance and m-Maestro in Switzerland (Ondrus et al., 2009), Telia Mobil wallet (Telia, 2012) and Bart in Sweden (SvD, 2014), and O2 Wallet in the UK (Clark, 2014) are just some of the services that were terminated.

According to Dahlberg et al. (2008), technological and consumer-related issues are the most common areas in the academic research of mobile payments. There is a lack of research focused on service adoption by merchants (Dahlberg et al., 2008; Ondrus and Lyytinen, 2011). This is an important problem to investigate because mobile payments are subject to indirect network externalities (Economides, 1996; van Hove, 1999) and have to be adopted by two sides: merchants and consumers.

The objective of this research is to explain why mobile payment services have not been widely adopted yet. In order to do this, we explore the expectations of the main groups of stakeholders - the mobile service providers, the retailers, and the consumers. As an example, we use the services applied in the retail industry in Sweden. We have made a number of propositions about stakeholder expectations' of mobile payment services. Then we (i) empirically tested and validated these propositions; and (ii) performed their qualitative assessment. Moreover, we have used the findings to define the most important criteria that mobile payment services should have in order to be adopted.

Due to rather fragmented research on mobile payments, stakeholders' expectations have not been explored by previous studies. However, findings of such research will help to define what mobile payment services are lacking in order to meet the needs of stakeholders in the best way possible. The key findings of this study highlight that mobile payment adoption depends on (i) the ability of mobile payment providers to build networks of both retailers and consumers simultaneously; and (ii) the degree to which this service meets the expectations and needs of stakeholders.

In order to develop conceptual basis, we sought to find similarities in the research on electronic and Internet payment services. We have also used the findings of research on service adoption in similar domains (e.g. adoption of electronic and mobile banking, electronic commerce, and mobile services) to develop the research framework.

In the rest of the paper we present the literature review on adoption of mobile payments by consumers and merchants followed by a discussion on the conceptual framework. Then we discuss methodology and present our research findings. Finally, we discuss these findings, and the theoretical and practical contributions. 


\section{Theoretical Background}

\subsection{Mobile Payments}

Mobile payments can be defined as 'a type of payment transaction processing in which the payer uses mobile communication techniques in conjunction with mobile devices for initiation, authorization, or completion of payment' (Goeke and Pousttchi, 2010:371). Parties that take part in the provisioning of mobile payments are mobile network operators, banks and financial companies, device manufacturers, software developers, service providers, customers, merchants, and regulation institutions (van der Heijden, 2002; Karnouskos and Fokus, 2004; Au and Kauffman, 2008). These actors can be classified in several groups: technology producers, mobile payment service providers, merchants, and consumers (Ondrus and Lyytinen, 2011).

The academic research on mobile payments has been fragmented. Research interests of scholars are mainly focused on the investigation of technical issues (e.g. related to mobile payment systems' architecture, security, trust, and protocols) and the study of consumer related issues (i.e. acceptance of technology). Other areas remain under-researched, for example, the impact of social and cultural factors on mobile payments, the comparison of traditional and mobile payment services, business-tobusiness aspects, analysis of roles and needs of service providers and merchants, etc. (Dahlberg et al., 2008; Ondrus and Lyytinen, 2011).

\subsection{Adoption of mobile payment services}

We use the theory of diffusion of innovations (Rogers, 2003), the Technology Adoption Model (TAM) (Davis, 1989), and network externalities (Economides, 1996; van Hove, 1999) as the main theoretical background of this research. A brief overview of the main theoretical points is given below.

\subsubsection{The acceptance of mobile payment systems by consumers}

The theory of diffusion of innovations and TAM initially served to explain the adoption and use of information technologies (Davis et al., 1989). Currently, they are commonly used in the analysis of mobile payment adoption (Dahlberg et al., 2008).

The theory of diffusion of innovations was proposed in 1962 by Rogers. The theory defines an innovation as 'an idea, practice, or object that is perceived as new by an individual or other unit of adoption' (Rogers, 2003:12). First, adoption of an innovation affects a small group of adopters, and then gradually spreads into the population. Rogers (2003:5) defines the process of diffusion as the communication of an innovation 'through certain channels over time among the members of a social system'. According to Rogers, the following five characteristics of innovation influence its adoption:

- Relative advantage: the degree to which an innovation is perceived better than the old practice.

- Compatibility: the degree to which an innovation is perceived as being consistent with the existing values, needs, and past experiences of potential adopters.

- Complexity: the degree to which an innovation is perceived as difficult to use.

- Trialability: the degree to which an innovation can be experimented on prior to adoption.

- Observability: the degree to which the results of an innovation are visible to others.

This framework was used to explain the adoption of new electronic and mobile financial services, such as Internet banking (Gerrard and Cunningham, 2003), mobile financial services (Chemingui and Ben lallouna, 2013), and mobile payments (Mallat, 2007; Arvidsson, 2014). 
Another widely used approach, TAM, was developed by Davis (1989:320) in order to predict the acceptance of technology by individuals within the organisation. The model consists of two variables:

- Perceived usefulness: the degree to which a person believes that using a particular system would enhance his or her job performance.

- Perceived ease of use: the degree to which a person believes that using a particular system would be free of effort.

Adoption of innovation is a complex process that is influenced by a number of factors. That is why researchers have developed extensions of TAM. One example is a unified theory of acceptance and use of technology model (UTAUT). This model predicts that four main constructs (performance expectancy, effort expectancy, social influence, and facilitating conditions) are 'direct determinants of user acceptance and usage behavior' (Venkatesh et al., 2003:447). A more complex model, UTAUT2, introduced three additional main constructs: hedonistic motivation (or perceived enjoyment), price value, and habit (Venkatesh et al., 2012). Social influence (Shin, 2009; Zhou et al., 2010; Yang et al., 2012) and perceived enjoyment (Chemingui and Ben lallouna, 2013) proved to be important indicators of mobile payment acceptance.

Researchers usually combine constructs of both TAM and diffusion of innovations frameworks and broaden the frameworks by bringing in additional factors. For example, in addition to perceived usefulness and ease-of-use, studies on electronic and mobile services highlighted the importance of security (Kim et al, 2010b), trust to service providers (Shin, 2009; Kim et al, 2010b; Duane et al., 2014), habit and price (Venkatesh et al., 2012), and use context (Mallat et al., 2009) for consumer adoption.

Researchers have used constructs of the technology acceptance model to study Internet banking adoption (Zhou et al., 2010; Yousafzai and Yani-de-Soriano, 2012; Harrison et al., 2014), mobile financial services (Hsu et al., 2011), and mobile banking (Luo et al, 2010; Püschel et al., 2010; Zhou et al., 2010). Constructs of TAM and diffusion of innovations models have been used to study adoption of electronic payment systems (Kim et al, 2010b), mobile commerce (Chong, 2013), mobile payments (Kim et al., 2010a; Goeke and Pousttchi, 2010; Schierz et al., 2010; Yang et al., 2012; Duane et al., 2014), mobile ticketing (Mallat et al., 2009), and mobile wallets (Shin, 2009).

Overall, the main contribution of related works is in the identification, qualitative assessments, and quantitative tests of factors affecting the intention to use mobile payments. Mallat (2007:428) has made an important theoretical contribution towards understanding what the mobile payment adoption is. The researcher has found that consumers are willing to use mobile payments in specific situations but do not see them as a substitute for already existing payment systems. This finding implies partial adoption. Moreover, consumers put a high importance on the reliability of such services, and trust in services is built via a learning process. Consequently, the launch of services must be designed as learning processes for consumers and merchants (Arvidsson, 2014). The summary of the most important factors that proved to have a significant influence for adoption of mobile and electronic financial services and payments is presented in Table 1. 


\begin{tabular}{|c|c|}
\hline $\begin{array}{l}\text { Supported factors which } \\
\text { positively affect adoption }\end{array}$ & References \\
\hline Ease of use & $\begin{array}{l}\text { Arvidsson, 2014; Chen, 2008; Chong, 2014; Constantiou et al., 2006; Duane et al., 2014; Goeke and } \\
\text { Pousttchi, 2010; Harrison et al., 2014; Hsu et al., 2011; Kim et al., 2010a; Mallat, 2007; Mallat et } \\
\text { al., 2009; Schierz et al., } 2010\end{array}$ \\
\hline Perceived usefulness & $\begin{array}{l}\text { Chen, 2008; Chong, 2014; Duane et al., 2014; Goeke and Pousttchi, 2010; Hsu et al., 2011; Kim et } \\
\text { al., 2010a; Schierz et al., 2010; Yousafzai and Yani-de-Soriano, } 2012\end{array}$ \\
\hline Relative advantage & $\begin{array}{l}\text { Arvidsson, 2014; Gerrard and Cunningham, 2003; Mallat, 2007; Püschel et al., 2010; Szmigin and } \\
\text { Bourne, 1999; Yang et al., } 2012\end{array}$ \\
\hline Compatibility & $\begin{array}{l}\text { Chen, 2008; Chemingui and Ben lallouna, 2013; Gerrard and Cunningham, 2003; Mallat, 2007; } \\
\text { Mallat et al., 2009; Püschel et al., 2010; Schierz et al., 2010; Szmigin and Bourne, 1999; Yang et al., } \\
2012\end{array}$ \\
\hline $\begin{array}{l}\text { Knowledge; Previous experience } \\
\text { of technology or service }\end{array}$ & $\begin{array}{l}\text { Gerrard and Cunningham, 2003; Harrison et al., 2014; Kim et al., 2010a; Laukkanen and Kiviniemi, } \\
\text { 2010; Luo et al., } 2010\end{array}$ \\
\hline Perceived security, Lack of risks & $\begin{array}{l}\text { Arvidsson, 2014; Harrison et al., 2014; Hsu et al., 2011; Kim et al., 2010b; Luo et al., 2010; Schierz } \\
\text { et al., 2010; Shin, 2009; Szmigin and Bourne, } 1999\end{array}$ \\
\hline Trust in actors & Arvidsson, 2014; Duane et al., 2014; Kim et al., 2010b; Mallat, 2007; Shin, 2009 \\
\hline Individual mobility & Constantiou et al., 2006; Kim et al., 2010a; Mallat et al., 2009; Schierz et al., 2010 \\
\hline Convenience & Constantiou et al., 2006; Gerrard and Cunningham, 2003; Harrison et al., 2014 \\
\hline Innovativeness & Duane et al., 2014; Gerrard and Cunningham, 2003; Kim et al., 2010a \\
\hline Social influence & Shin, 2009; Yang et al., 2012; Zhou et al., 2010 \\
\hline Use context & Mallat, 2007; Mallat et al., 2009 \\
\hline $\begin{array}{l}\text { Supported factors which } \\
\text { negatively affect adoption }\end{array}$ & References \\
\hline $\begin{array}{l}\text { Perceived risks (security and } \\
\text { privacy) }\end{array}$ & $\begin{array}{l}\text { Arvidsson, 2014; Chen, 2008; Gerrard and Cunningham, 2003; Kim et al., 2010b; Mallat, 2007; } \\
\text { Szmigin and Bourne, 1999; Yang et al., } 2012\end{array}$ \\
\hline Cost & Constantiou et al., 2006; Harrison et al., 2014; Venkatesh et al., 2012; Yang et al., 2012 \\
\hline $\begin{array}{l}\text { Network externalities, Lack of } \\
\text { merchant adoption, Lack of } \\
\text { critical mass }\end{array}$ & Goeke and Pousttchi, 2010; Kauffman et al., 2000; Mallat, 2007 \\
\hline Complexity & Szmigin and Bourne, 1999 \\
\hline
\end{tabular}

\subsubsection{The acceptance of mobile payment systems by organisations}

The main approach used in studies of organisational adoption is the theory of diffusion of innovations (Rogers, 2003). However, the number of studies addressing problems of organisational technology acceptance in the mobile payment, m-commerce, and related areas is not extensive. This could be explained by the general complexity of the question because the study should consider two levels: organisational and intra-organisational (Frambach and Schillewaert, 2002). The main factors affecting innovation adoption at the organisational level are adopter characteristics, supplier marketing activity, perceived innovation characteristics, social network, and environmental influences. On the intraorganisational level important factors include personal characteristics, internal facilitation, social usage, personal innovativeness, and attitudes towards innovation.

Studies of organisational adoption have been conducted in the domains of electronic and telecommunication services (Mahler and Rogers, 1999), information and communication technology (Chwelos et al., 2001; Lapierre and Denier, 2005), e-businesses (Oliveire and Martins, 2010), and emarkets (Johnson, 2009; 2010). Mallat and Tuunainen (2008) and van der Heijden (2002) have addressed the adoption of mobile payments by retailers. Factors affecting organisational acceptance of mobile and electronic services are summarised in Table 2. 
Table 2. Factors influencing the adoption of mobile and electronic services by organisations.

\begin{tabular}{|c|c|}
\hline Factors which positively affect adoption & Factors which negatively affect adoption \\
\hline \multicolumn{2}{|c|}{ Perceived innovation characteristics } \\
\hline $\begin{array}{l}\text { - Relative advantage (Frambach and Schillewaert, 2002; Plouffe et } \\
\text { al., 2000) } \\
\text { - Compatibility (Frambach and Schillewaert, 2002) } \\
\text { - Trialability (Frambach and Schillewaert, 2002) } \\
\text { - Observability (Frambach and Schillewaert, 2002) } \\
\text { - Ease-of-use (van der Heijden, 2002) } \\
\text { - Perceived benefits (Chwelos et al., 2001; Mallat and Tuunainen, } \\
\text { 2008; Oliveira and Martins, 2010) } \\
\text { - Image (Plouffe et al., 2000) }\end{array}$ & $\begin{array}{l}\text { - Complexity (Frambach and Schillewaert, 2002; Mallat and } \\
\text { Tuunainen, 2008) } \\
\text { - Incompatibility (Mallat and Tuunainen, 2008) } \\
\text { - Uncertainty (Frambach and Schillewaert, 2002) } \\
\text { - Cost (Transaction fee, Bad price/value ratio) (Mallat and } \\
\text { Tuunainen, 2008; Mahler and Rogers, 1999; Plouffe et al., 2000; } \\
\text { van der Heijden, 2002) } \\
\text { - Perceived risks (security, privacy, investment) (Mallat and } \\
\text { Tuunainen, 2008; Johnson, 2009; Oliveira and Martins, 2010; } \\
\text { Plouffe et al., 2000; van der Heijden, 2002) }\end{array}$ \\
\hline \multicolumn{2}{|c|}{ Technical feasibility } \\
\hline $\begin{array}{l}\text { - Technology integration (van der Heijden, 2002; Oliveira and } \\
\text { Martins, 2010) } \\
\text { - Interoperability (van der Heijden, 2002) } \\
\text { - Scalability (van der Heijden, 2002) } \\
\text { - Remote access (van der Heijden, 2002) } \\
\text { - Reliability (Mahler and Rogers, 1999) } \\
\text { - Technology readiness (infrastructure and personnel) } \\
\text { (Johnson, 2009; Mallat and Tuunainen, 2008; Oliveira and } \\
\text { Martins, 2010; Chwelos et al., 2001) }\end{array}$ & $\begin{array}{l}\text { - Poor quality of service (Mahler and Rogers, 1999) } \\
\text { - Lack of service standards (Mallat and Tuunainen, 2008; Mahler } \\
\text { and Rogers, 1999) } \\
\text { - Long processing time (Mahler and Rogers, 1999; Plouffe et al., } \\
\text { 2000) }\end{array}$ \\
\hline \multicolumn{2}{|c|}{ Organisational readiness } \\
\hline $\begin{array}{l}\text { - Financial resources (Chwelos et al., 2001) } \\
\text { - Readiness of trading parties (Chwelos et al., 2001; Johnson, 2009; } \\
\text { Oliveira and Martins, 2010) } \\
\text { - Knowledge (Mallat and Tuunainen, 2008) } \\
\text { - Need for an alternative payment system (Mallat and Tuunainen, } \\
\text { 2008) }\end{array}$ & $\begin{array}{l}\text { - Lack of knowledge (Johnson, 2009) } \\
\text { - Lack of trust in partners (Johnson, 2009; Mallat and Tuunainen, } \\
\text { 2008) }\end{array}$ \\
\hline \multicolumn{2}{|c|}{ Adopter characteristics } \\
\hline $\begin{array}{l}\text { - Structure (Frambach and Schillewaert, 2002; Rogers, 2003) } \\
\text { - Size (Frambach and Schillewaert, 2002; Rogers, 2003; Lapierre } \\
\text { and Denier, 2005) } \\
\text { - Innovativeness (Frambach and Schillewaert, 2002; Mahler and } \\
\text { Rogers, 1999; Rogers, 2003) }\end{array}$ & $\begin{array}{l}\text { - Structure (Frambach and Schillewaert, 2002; Rogers, 2003) } \\
\text { - Size (Johnson, 2009) }\end{array}$ \\
\hline \multicolumn{2}{|c|}{ Suppliers' marketing effort } \\
\hline $\begin{array}{l}\text { - Targeting (Frambach and Schillewaert, 2002) } \\
\text { - Communication (Frambach and Schillewaert, 2002) } \\
\text { - Risk reduction (Frambach and Schillewaert, 2002) }\end{array}$ & $\begin{array}{l}\text { - Lack of information from suppliers (Mahler and Rogers, 1999; } \\
\text { Plouffe et al., 2000) }\end{array}$ \\
\hline \multicolumn{2}{|c|}{ Social network } \\
\hline \multicolumn{2}{|c|}{\begin{tabular}{l|l} 
- Network participation (Frambach and Schillewaert, 2002; Rogers, & \\
2003) & \\
\end{tabular}} \\
\hline \multicolumn{2}{|c|}{ Environmental and external pressure } \\
\hline $\begin{array}{l}\text { - Network externalities (Frambach and Schillewaert, 2002) } \\
\text { - Competitive pressures (Chwelos et al., 2001; Frambach and } \\
\text { Schillewaert, 2002; Oliveira and Martins, 2010) }\end{array}$ & $\begin{array}{l}\text { - Competitive pressures (Frambach and Schillewaert, 2002) } \\
\text { - Low rate of diffusion (Mahler and Rogers, 1999) } \\
\text { - Lack of critical mass (Mallat and Tuunainen, 2008; van der } \\
\text { Heijden, 2002) }\end{array}$ \\
\hline \multicolumn{2}{|c|}{ Intra-organisational factors } \\
\hline $\begin{array}{l}\text { - Organisational culture (Lapierre and Denier, 2005) } \\
\text { - Organisational learning (Johnson, 2009) } \\
\text { - Organisational facilitators (Frambach and Schillewaert, } \\
\text { 2002) } \\
\text { - Personal innovativeness (Frambach and Schillewaert, 2002) } \\
\text { - Individual positive attitudes towards a new service (Lapierre } \\
\text { and Denier, 2005) } \\
\text { - Social influence (Frambach and Schillewaert, 2002) }\end{array}$ & $\begin{array}{l}\text { - Resistance to change from employees (Johnson, 2009; Johnson, } \\
\text { 2010; Mahler and Rogers, 1999) } \\
\text { - Personal innovativeness (Frambach and Schillewaert, 2002) }\end{array}$ \\
\hline
\end{tabular}

\subsubsection{Network externalities and critical mass}

Network externalities are an important factor which hinders the adoption of new payment instruments. This was supported by empirical studies on the adoption of electronic money (van Hove, 1999), smart payment cards (Plouffe et al., 2000), a shared electronic banking network by banks (Kauffman et al., 2000), and mobile payments (Mallat, 2007). Moreover, network externalities result in a significant 
delay of growth rates of a new product (Goldenberg et al., 2010). This effect has negative implications on a company's profit in the early stages of the product life cycle.

Many technologies exhibit direct network externalities, which mean that the value of a service or a product for a user increases with a number of its adopters (Economides, 1996; Song et al., 2009). Several examples of such technologies are telephones and fax machines. However, payment services should be adopted by two sides, both merchants and consumers (Plouffe et al., 2000). Hence, these services are subject to indirect network externalities (Economides, 1996; van Hove, 1999). The size of the merchant network affects the consumer's decision to adopt the service. At the same time, new service consumers indirectly increase the value of a network, making it attractive for merchants to join (Mallat, 2007).

Mobile payment service providers must 'not only market their product but also develop and market the product's network' (Srinivasan et al., 2004). They deal with a 'chicken and egg' dilemma: merchants are unwilling to invest in a service and its infrastructure without a critical mass of consumers, and consumers will not use a new means of payment if it cannot be used everywhere (van Hove, 1999; Mallat, 2007). Critical mass can be defined as 'the minimum number of adopters of an interactive innovation for the future rate of adoption to be self-sustaining' (Mahler and Rogers, 1999:721). As previous studies (Szmigin and Bourne, 1999; Plouffe et al., 2000; van Hove, 2001) show, the inability to reach a critical mass becomes a reason for the failure of payment systems.

\section{Conceptualisation of stakeholders' expectations}

We have developed a conceptual framework based on a literature review analysis. The main dimensions are stakeholders and expectations.

Stakeholders. In Sweden the main stakeholders of POS mobile payment services are mobile payment service providers, banks, financial companies, merchants (i.e. retail and restaurant chains), and consumers. Historically, mobile network operators were not interested in these services.

Expectations. In order to be adopted in the market, mobile payment system needs to meet the expectations of the banks and financial institutions, merchants, and consumers (Karnouskos and Fokus, 2004). For our analytical framework we have selected six criteria (technological feasibility, economic benefits, lower service cost, added value of services, network externalities and critical mass, and ease of use) as they are the most frequently referred to in the literature.

\section{Technological feasibility}

The main technical issues of mobile payment systems are standardisation, a lack of interoperability, transaction security, privacy, and integration of a new payment system into the overall business environment (Au and Kauffman, 2008; Mallat and Tuunainen, 2008; Barbuta et al., 2012).

Banks expect a secure and trusted service and integration of a new payment into the existing infrastructure (Karnouskos and Fokus, 2004; Barbuta et al., 2012). Factors affecting mobile payment system acceptance by merchants are independence (i.e. no need for specialised hardware and software), scalability, and security (van der Heijden, 2002). A payment system should also be standardised, easily integrated, interoperable, and trusted (Karnouskos and Fokus, 2004). In addition, merchants expect mobile payment transactions to be faster than bank cards (Karnouskos and Fokus, 2004).

End-users expect interoperability between devices (Karnouskos and Fokus, 2004), anonymity of transactions (similar to paying with cash) and privacy (Karnouskos and Fokus, 2004), and a secure high-quality service (van der Heijden, 2002; Karnouskos and Fokus, 2004; Constantiou et al., 2006). Customer-perceived security positively affects trust in services and the intention to use a payment system (Kim et al., 2010b). 
Technological feasibility of a service is important for banks, merchants, and consumers. This leads us to the following proposition:

Proposition 1. Banks expect a mobile payment service to be secure, trusted, and easy to integrate into the existing infrastructure. Merchants also expect a new mobile payment service to be easily integrated with other payment services and back-end systems, and that the service is fast, reliable, scalable, and secure. Consumers expect a fast, reliable, secure, and trustworthy service with guaranteed privacy and anonymity.

\section{Dimensions of relative advantage}

The essential contribution of the previous studies is in the attempt to define the relative advantage of mobile services (i.e. mobile commerce, banking, and payment). Convenience and independence of location and time are the main factors which affect the intention to use mobile services (Frolick and Chen, 2004; Constantiou et al., 2006; Laukkanen and Kiviniemi, 2010). Similarly, Mallat (2007:427) has defined the relative advantage of mobile payments for consumers as 'the perceived independence of time and place, availability to avoid queues, and the ability to complement traditional services (cash payments)'. It is possible to specify several dimensions of relative advantage: economic benefits, lower service cost, and added value of a service.

Economic benefits are one of the most important factors of relative advantage. When entering the payment market, mobile payment providers expect to gain their market share by attracting more merchants and consumers. Banks expect to find new business cases (Karnouskos and Fokus, 2004; Mallat and Tuunainen, 2008). Merchants expect to increase their transaction volumes and revenue, to attract new segments of consumers, and to increase the number of impulse purchases (Chen, 2008; Mallat and Tuunainen, 2008). We propose that economic benefits are important for companies:

Proposition 2. Banks and financial companies expect to find new business cases from the introduction of mobile payments. Mobile payment providers expect to gain a bigger share of the payment market. Merchants expect that a new mobile payment service will serve to increase the number of impulse purchases, to increase the transaction volumes, and to reach new market segments.

Lower service costs. Cost factor is a construct of relative advantage (Rogers, 2003). However, in a number of studies on the adoption of mobile commerce, financial and payment services (Mallat, 2007; Hsu et al., 2011; Arvidsson, 2014), researchers treat it as a separate variable. According to the findings, the price of mobile services is the most important factor for service adoption by consumers (Constantiou et al., 2006) and negatively affects consumers' intention to use the service (Mallat, 2007). Indeed, cash payment has no cost for consumers, and they expect the cost of a mobile payment service to be low or zero (Karnouskos and Fokus, 2004).

Merchants represent a group of stakeholders who pay the payment system provider for the service (van der Heijden, 2002). Merchants will perceive a mobile payment service as an attractive alternative if it can ensure lower transaction costs compared to bank card systems (van der Heijden, 2002; Karnouskos and Fokus, 2004; Mallat and Tuunainen, 2008; Chen, 2008). Furthermore, the cost of investment in the service infrastructure is also expected to be low or zero (Karnouskos and Fokus, 2004). An additional category of costs for merchants is personnel learning and training costs (van der Heijden, 2002). We propose that the cost factor is important for merchants and consumers:

Proposition 3. Both groups of stakeholders expect that mobile payment services will ensure lower service and operational costs.

Added value of a service. Mobile payment services compete with cash, bank cards, and other means of payment. In this context, a key success factor for mobile payment providers becomes delivering value added services to customers (both retailers and consumers) (Laukkanen and Kiviniemi, 2010).

Researchers (Frolick and Chen, 2004) have defined mobile commerce as a channel that can be used to enhance customer relationships for direct marketing and for promotional activities. Ondrus and Lyytinen (2011) have specified loyalty schemes and promotion options as value for merchants. The 
introduction of mobile payment services has potential to improve a company's image and branding (Karnouskos and Fokus, 2004; Mallat and Tuunainen, 2008), customer loyalty (Karnouskos and Fokus, 2004; Chen, 2008), and to enhance customer service (Chen, 2008). Additionally, merchants have the possibility to customise the service by adding loyalty schemes to the mobile payment service and to simplify payment procedures (Karnouskos and Fokus, 2004).

Service convenience and access to information (Frolick and Chen, 2004; Chen, 2008) and integration with other mobile services (Ondrus and Lyytinen, 2011) are the added value of mobile commerce for consumers. Other added value services of mobile payments are service personalisation (Constantiou et al., 2006); person-to-person transactions, overview of real-time transaction status, and the ability to pay 'anywhere' and 'anytime' (Karnouskos and Fokus, 2004; Mallat, 2007).

We propose that expected added value of a service is important for merchants and consumers:

Proposition 4. Merchants expect to improve the company's image and customer loyalty, to enhance customer service, to simplify and speed-up purchasing processes, to integrate loyalty schemes, and to use the service for direct marketing and promotional campaign purposes. Consumers expect a convenient, personalised service integrated with other mobile services (e.g. ticketing, loyalty schemes, etc.).

\section{Network externalities and critical mass}

Previous studies on the adoption of new payment systems like smart cards (Plouffe et al., 2000) and mobile payments (van der Heijden, 2002; Mallat and Tuunainen, 2008; Au and Kauffman, 2008) emphasise the interdependence of two major groups of stakeholders - merchants and consumers - in the service's adoption and use. Consumers can benefit from a payment service only if it is accepted by an extended network of retailers, merchants, and restaurants (Plouffe et al., 2000; Karnouskos and Fokus, 2004; Goeke and Pousttchi, 2010). Merchants are interested in the service deployment only if there is a critical mass of consumers (Plouffe et al., 2000; Mallat and Tuunainen, 2008). Mobile payment providers can benefit if both networks are big (Karnouskos and Fokus, 2004) and, thus, there is a considerable number of transactions. This leads us to the following proposition:

Proposition 5. Mobile payment providers expect to attract a big network of merchants who will accept the payment service, and consumers who will use it. Merchants expect that there will be a critical mass of consumers. Consumers expect a ubiquitous mobile payment service infrastructure.

\section{Ease of use}

Findings from previous research (Constantiou et al., 2006; Goeke and Pousttchi, 2010; Kim et al., 2010a; Hsu et al., 2011; Duane et al., 2014) have shown that ease of use is crucial for adoption of mobile services. Moreover, ease of use contributes to the overall consumer satisfaction from mobile services (Constantiou et al., 2006) and influences whether consumers are likely to use a mobile payment service (Arvidsson, 2014). According to Kim et al. (2010a), knowledge, innovativeness, reachability, and convenience are relevant factors which can explain an ease of use variable. Service simplicity, a user-friendly interface, and minimum or zero learning effort also are very important (Karnouskos and Fokus, 2004). From the perspective of merchants, the service should be easy to use for personnel (van der Heijden, 2002).

Proposition 6. Merchants expect an easy to use mobile payment service, which does not require large learning costs and is user-friendly for their personnel. Consumers expect a simple and user-friendly solution. 
Table 3.

Analysis framework.

\begin{tabular}{|l|c|c|c|c|}
\hline Expectations & $\begin{array}{c}\text { Mobile payment } \\
\text { service providers }\end{array}$ & Banks & Merchants & Consumers \\
\hline \hline Technological feasibility (P1) & & $\bullet$ & $\bullet$ & $\bullet$ \\
\hline Economic benefits (P2) & $\bullet$ & $\bullet$ & $\bullet$ & \\
\hline Lower service cost (P3) & & & $\bullet$ & $\bullet$ \\
\hline Added value of a service (P4) & & $\bullet$ & $\bullet$ & $\bullet$ \\
\hline Network externalities and critical mass (P5) & $\bullet$ & & $\bullet$ & $\bullet$ \\
\hline Ease of use (P6) & & $\bullet$ & $\bullet$ \\
\hline
\end{tabular}

We have summarised our propositions (P1 - P6) in Table 3. These assumptions were (i) validated during interviews with stakeholders; and (ii) assessed whether they were fulfilled or not.

\section{Methodology}

\subsection{Methodological choices}

The purpose of our research is to explore stakeholders' expectations regarding mobile payment services. Due to the explorative nature of the study, we have selected a qualitative method utilising a case study approach. This is in line with the tradition of interpretive and exploratory research applied in information systems (Orlikowski and Baroudi, 1991; Klein and Myers, 1999). Thus, the main objective of interpretive researchers is to 'attempt to understand phenomena through accessing the meanings that participants assign to them' (Orlikowski and Baroudi, 1991:5).

Researchers frequently use qualitative studies in the analysis of adoption of payment systems (Szmigin and Bourne, 1999; Plouffe et al., 2000), Internet banking (Gerrard and Cunningham, 2003), businessto-business, e-commerce, and e-markets (Johnson, 2009; 2010), and mobile payment services (van der Heijden, 2002; Mallat, 2007). These studies are often interview-based (Szmigin and Bourne, 1999; van der Heijden, 2002; Gerrard and Cunningham, 2003) or case study-based (Johnson, 2009; 2010).

One benefit of a case study is the opportunity to study 'a phenomenon over time within its natural settings in one or a few sites' (Bhattacherjee, 2012:94). In addition, multiple methods of data collection including 'archives, interviews, questionnaires, and observations' (Eisenhardt, 1989:534) provide a rich and contextualized data about the phenomenon in focus (Bhattacherjee, 2012).

\subsection{Data collection}

We used secondary data in order to collect background information about mobile payment services. The main sources were press releases, reports, and other documents related to the companies of interest.

We gathered primary data during interviews, retail events and conferences, and with the help of a questionnaire. We carried out a number of in-depth personal interviews with top- and middle-level managers representing mobile payment service providers (Seamless and Swedbank) and the retailer (Axfood) in 2014. The questions discussed during the semi-structured interviews were related to:

- The initial expectations that these stakeholders had before the service deployment.

- Whether or not the expectations were fulfilled after the service deployment.

The duration of the interviews varied from one to two hours. All interviews were recorded and transcribed. Additionally, we sent a questionnaire covering the same questions to a representative of McDonald's. The questionnaire is presented in Appendix A. 
Finally, we attended presentations of companies of interest during events dedicated to retail, such as Retail Day 2013 (Retaildagen), Retail Forum 2013, and Cashless Society Roundtable 2014. Additionally, after the Seamless presentation at Retail Forum 2013, we had a discussion with the representative of the company. The sources of research data are summarised in Table 4.

\section{Table 4. Research data gathering.}

\begin{tabular}{|l|l|}
\hline Type of the meeting & Attendees \\
\hline $\begin{array}{l}\text { Presentation during Retail Forum } 2013 \text { and personal } \\
\text { discussion }\end{array}$ & Seamless, Regional manager \\
\hline Interview & Swedbank, Bart service developer \\
\hline Interview & Axfood, Middle-level project manager \\
\hline Interview & Seamless, Middle-level project manager \\
\hline Questionnaire & McDonald's, Middle-level manager \\
\hline
\end{tabular}

This research also builds on findings from the previous studies conducted in 2010-2013. During this period a number of meetings with major stakeholders were organised in order to discuss solutions, drivers, and obstacles related to mobile payments. These issues were discussed in-depth with Swedbank and ICA Banken, and the payment service providers Mobill, PayEx, Payair, and WyWallet (Arvidsson, 2013; Markendahl, 2013). Additionally, in June 2012 a workshop on payment solutions was organised with representatives from parking, retail, and transportation companies (Arvidsson, 2013).

In order to perform the analysis, we wrote descriptions of mobile payment cases. The case information was based on observations, secondary data, and interviews. Due to the relatively limited number of interviews, we performed content analysis without the use of specialised software. We have categorised the expectations of different stakeholders according to the criteria specified in the analysis framework (see Table 3). Then we tested and validated our propositions (P1 - P6) based on the qualitative data. Moreover, we performed a comparison of stakeholders' expectations across cases and have compared our findings with the extant literature.

\section{Research findings}

In the Swedish market, there are three services that are suitable for POS payments: SEQR provided by Seamless, Bart provided by Swedbank, and Payair provided by Payair. Currently, many retail shops and restaurants have deployed SEQR and Bart services. We have excluded Payair from the current research because it has mainly been used in online shops and in printed advertisements.

\subsection{Mobile payment service Bart}

\subsubsection{Bart service description}

Swedbank introduced the service in 2011. The service provisioning did not require new business actors. In the beginning the service was limited to only Swedbank customers, but later it became available for customers of other banks. The initial aim of the service was to enhance the purchasing experience and to provide a range of additional services. However, only the payment option was implemented. In terms of infrastructure, the service required a separate payment terminal - a Bart reader. From an end-user perspective, the service was designed for all types of smartphones. The service registration required approximately 5 minutes of consumer's time in order to download the Bart app and to connect it to a bank account. 
The only retailer that adopted the service was Axfood, the third largest retail chain in Sweden. As a partner, Axfood participated in the development of the Bart reader's design. In November 2012, Axfood started a pilot project with Bart in three shops in Stockholm (Axfood, 2012). By April 2013, the service was installed in 400 stores in the Axfood's grocery chains (i.e. Hemköp and Willys) all over Sweden.

On the $28^{\text {th }}$ of February 2014, Swedbank ceased the Bart service (SvD, 2014). By that time, the number of service users had reached 20,000.

\subsubsection{Stakeholder expectations of the Bart service}

The main categories of stakeholders are the mobile payment service provider, one retailer, and consumers. The mobile payment service provider is Swedbank. The retailer is Axfood. The end-users of the Bart service are mainly customers of Swedbank and Axfood. The summary of findings related to stakeholder expectation on the Bart service is presented in Table 5.

Table 5. Fulfilment of stakeholders' expectations on the Bart service.

\begin{tabular}{|l|c|c|c|}
\hline Expectations & $\begin{array}{c}\text { Swedbank } \\
\text { (Mobile payment service provider / Bank) }\end{array}$ & $\begin{array}{c}\text { Axfood } \\
\text { (Merchant) }\end{array}$ & Consumers \\
\hline \hline Technological feasibility (P1) & Yes & Partly & Yes \\
\hline Economic benefits (P2) & No & No & \\
\hline Lower service cost (P3) & & Partly & Yes \\
\hline Added value of a service (P4) & No & No & No \\
\hline Network externalities and critical mass (P5) & & No & No \\
\hline Ease of use (P6) & & No \\
\hline
\end{tabular}

\section{Technological feasibility}

Swedbank. The service was initially designed as an integral part of the existing infrastructure used for bank card payments. The developed solution was trusted and highly secure: payments were performed offline and no sensitive information was sent. From the bank's perspective, the service was easily integrated into the existing payment infrastructure. In addition, bank's representatives perceived a direct link between mobile payment service and customers' bank accounts as a clear strength of this solution.

Axfood. From the technological point of view, Bart met the expectations of the merchant. The service was easy to integrate into the existing infrastructure, it performed well, and it was secure, reliable, and fast. However, the need for separate hardware was considered to be a weakness of the service because the area around the cash register 'is very valuable' and should be 'as clean as possible'. Additionally, the duration of the payment procedure directly depended on the experience of consumers. It took 'a bit more time' for first-time users.

Consumers. The service was compatible with all smartphones. It was secure, and it was quick for experienced users.

\section{Economic benefits}

Swedbank. The bank was expecting a new business case and the opportunity to expand a range of provided services. However, the bank's expectations were not fulfilled and the service ceased.

Axfood. The retailer deployed Bart because it expected 'to reduce the amount of cash' and the risks associated with its handling. These expectations did not come true due to the small number of users and limited number of transactions. 


\section{Lower service cost}

Axfood. The expectation of a 'lower transaction cost' compared to bank cards was the main reason Axfood decided to deploy Bart. Whether this expectation came true was not disclosed in the interview.

Consumers. The Bart service was free of charge for consumers.

\section{Added value of a service}

Swedbank. The bank opened up the service for clients of other banks. This was considered an added value to customers and a low barrier to start using the service.

Axfood. The company decided to try a mobile payment service, being the first in the market. One of the benefits was getting more experience in offering the service. Another benefit was the attention they received from national and regional media. However, the company's representative noticed that Bart was just a payment and lacked 'extra services' for consumers.

Consumers. The service did not provide any additional services.

\section{Network externalities and critical mass}

Swedbank. The number of users was insufficient. Moreover, only one Swedish retailer deployed the service.

Axfood. A small number of users was the major problem of the service: ' 20,000 users is too few'.

Consumers. There was no network of retailers accepting the service.

\section{Ease of use}

Axfood. Bart was supposed to be easy for the personnel. However, because the transaction was rarely performed, cashiers 'forget or become unsure about how to do it'.

Consumers. Consumers were unsure about how to use the service.

\subsection{Mobile payment service SEQR}

\subsubsection{SEQR service description}

Seamless introduced the SEQR service in spring 2012 (Seamless, 2012). The service is provided in collaboration with financial service companies Collector and Gothia. These companies handle all questions related to payment transfers and consumer billing. Hence, all SEQR users have to register a credit account at one of these companies (Seamless, 2012).

Seamless has developed its own service network. Hence, there is no dependence on customers' affiliated banks and Visa or MasterCard payment networks. In 2013, SEQR was integrated with the cash register system LS Retail and does not require additional hardware in shops.

From a consumer perspective, the service app is available for iOS, Android, and Windows operational systems. Consumers can use the service free of charge.

In 2012-2013, Seamless was focused on the development of a network of merchants. Seamless offers a transaction fee that is 50\% less than credit card transaction fees. In the case of a big database of customers, this offer would allow retailers considerable financial savings. Additionally, the service 
roll-out is free for retailers. In spring 2014, there were more than 100 restaurant, retail, and coffee shop chains accepting SEQR at about 800 stores.

From the end of 2013, Seamless started targeting consumers. The company upgraded the service with new features: (i) loyalty accounts with several big retailers (Axfood's chains Hemköp and Willys; and Apoteksgruppen); and (ii) a cashback payment where the consumer gets money back when paying with SEQR for certain products. Other services integrated with SEQR are digital bills, person-toperson payments, parking payments, p-commerce (purchases in printed advertisements), and public transport ticketing in Skåne.

Selected retailers are Axfood, the third largest retail network, and McDonald's, a fast-food restaurant chain. Axfood started a pilot project with SEQR in spring 2012. At the end of 2012, SEQR was introduced in Axfood's grocery store chains (i.e. Hemköp, Willys, and PrisXtra). McDonald's started a pilot project at four restaurants in summer 2012 (Seamless, 2013). The pilot project was successful and resulted in an agreement to introduce SEQR in other chain restaurants. In spring 2014, Axfood (about 400 stores) together with McDonald's (about 220 restaurants) represented a considerable share of stores (out of about 800) accepting the SEQR service.

\subsubsection{Stakeholder expectations of the SEQR service}

The main categories of stakeholders are the mobile payment service provider, financial institutions, merchants, and consumers. The mobile payment service provider is Seamless. Gothia and Collector are the financial institutions that deal with payment transactions. Two contacted merchants are Axfood and McDonald's. We present the summary of findings related to stakeholder expectation on the SEQR service in Table 6.

Table 6. Fulfilment of stakeholders' expectations on the SEQR service.

\begin{tabular}{|c|c|c|c|c|c|}
\hline Expectations & $\begin{array}{c}\text { Seamless } \\
\text { (mobile payment } \\
\text { service provider) }\end{array}$ & $\begin{array}{l}\text { Gothia and Collector } \\
\text { (Financial companies) }\end{array}$ & $\begin{array}{c}\text { Axfood } \\
\text { (Merchant) }\end{array}$ & $\begin{array}{l}\text { McDonald's } \\
\text { (Merchant) }\end{array}$ & Consumers \\
\hline Technological feasibility (P1) & & & Partly & Yes & Yes \\
\hline Economic benefits (P2) & Yes & Yes & No & No & \\
\hline Lower service cost $(\mathrm{P} 3)$ & & & Yes & Yes & Yes \\
\hline Added value of a service (P4) & & & Yes & Yes & Yes \\
\hline $\begin{array}{l}\text { Network externalities and } \\
\text { critical mass (P5) }\end{array}$ & Yes & & No & No & Yes \\
\hline Ease of use (P6) & & & Yes & Yes & Yes \\
\hline
\end{tabular}

\section{Technological feasibility}

Seamless. SEQR is secure and trusted, with no sensitive information being sent during the transaction. Merchants report that a SEQR transaction 'is much faster than a card transaction' and the 'line goes quicker'.

Axfood and McDonald's. Neither retailer noticed any technical problems related to the service nor to the service roll-out process. The service is easy to integrate into the existing infrastructure, and it does not require hardware installation. However, the SEQR payment is performed online. The representative from Axfood did mention problems related to 'Internet access in the stores or in some parts of the stores'. Due to these problems, 'it is not possible to pay with SEQR' in several stores.

Consumers. The service is secure and fast. 


\section{Economic benefits}

Seamless. The development of an own service network allows the company to set a competitive transaction fee. Currently, it is ' $50 \%$ less than the one offered by credit card companies'. The main expectation is to gain a bigger market share of the payment market by attracting both retailers and consumers.

Gothia and Collector. All SEQR users need to open an account at Gothia or Collector. Hence, these companies get new clients, thereby increasing their market share and profit.

Axfood and McDonald's. Both retailers expect to reduce the amount of cash in the stores which is beneficial for safety reasons. However, the number of users and the number of transactions is not big, therefore this expectation has not yet been fulfilled.

\section{Lower service cost}

Axfood and McDonald's. The expectation of a lower transaction cost compared to bank cards became the reason for both retailers to introduce SEQR. According to the McDonald's representative, the service is attractive because it does not require additional investment in hardware upgrades or installation. Another benefit is the free service rollout mentioned by the Axfood representative. This means that retailers have no concerns about the return on investment.

Consumers. For consumers the SEQR service is free of charge.

\section{Added value of a service}

Seamless. In order to attract both merchants and retailers, the company adjusts the service according to their needs. The service has introduced new options: cashback payment and loyalty programmes with some retailers.

Axfood and McDonald's. Both companies see the introduction of SEQR as an opportunity to learn how to provide this type of service. Axfood was the first company that introduced a mobile payment. They received a lot of local and national media attention. Integrated loyalty cards and cashback payments represent additional value for Axfood. These two options can stimulate an increase in purchase volume and promote the merchants' and products' brands. For McDonald's the introduction of SEQR has potential to improve the company's brand perception ('modern brand') and to accept different types of payments: cash, bank cards, or mobile.

Consumers. SEQR added value includes integrated loyalty cards and other additional services (saved bills, person-to-person transfers, p-commerce, purchases online, transport tickets, and parking payments). The new feature - cashback payments - allows consumers to save money when buying certain products.

\section{Network externalities and critical mass}

Seamless. 'The company realised a need to develop a network of merchants before the consumers would come.' Realising the fact that 'there should be a business case for merchants', Seamless offered a transaction fee which is 50\% less than the credit cards' transaction fee. Additionally, there is no cost for rolling the service out in stores. The number of merchants who accept SEQR is increasing. At the same time, there is a business case for Seamless because gaining even $1 \%$ of the market is profitable. Seamless expects to attract consumers by stating: 'Earn money paying with SEQR' (i.e. cashback payment) and by providing additional services. 
Axfood and McDonald's. Representatives of the companies stated that the number of users is not big, consequently, the amount of transactions is small. The representative from McDonald's additionally stated that a problem of critical mass was not important 'since no investment was needed'.

Consumers. The network of retailers accepting the service is growing.

\section{Ease of use}

Axfood and McDonald's. Representatives of both retailers stated that SEQR is very easy for the personnel to learn and to use. According to the representative from Axfood, SEQR is easier to use for consumers in comparison to Bart.

\subsection{Comparative analysis of cases}

The settings of the analysed cases are unique because the same retailer (Axfood) adopted both mobile payment services during the same time period. These settings are close to the settings of a controlled experiment even though it was not organised by the researchers. Similarities and differences between the expectations of the main stakeholders are presented in Table 7 and focus on Axfood's experience.

Table 7. Comparison of the stakeholders' expectations of Bart and SEQR.

\begin{tabular}{|c|c|c|c|c|c|c|}
\hline \multirow[t]{2}{*}{ Expectations } & \multicolumn{2}{|c|}{$\begin{array}{l}\text { Mobile payment } \\
\text { service provider }\end{array}$} & \multicolumn{2}{|c|}{ Merchant (Axfood) } & \multicolumn{2}{|c|}{ Consumers } \\
\hline & Bart & SEQR & Bart & SEQR & Bart & SEQR \\
\hline Technological feasibility (P1) & & & Partly & Partly & Yes & Yes \\
\hline Economic benefits (P2) & No & Yes & No & No & & \\
\hline Lower service cost $(\mathrm{P} 3)$ & & & $?$ & Yes & Yes & Yes \\
\hline Added value of a service (P4) & & & Partly & Yes & No & Yes \\
\hline Network externalities and critical mass (P5) & No & Yes & No & No & No & Yes \\
\hline Ease of use (P6) & & & No & Yes & No & Yes \\
\hline
\end{tabular}

Mobile payment service providers. Bart service neither had an extended network of retailers, nor a critical mass of consumers. As a result, the service was not economically beneficial for Swedbank and was closed. In contrary, the number of merchants and end-users who accept SEQR is increasing. Hence, the service meets expectations of Seamless regarding economic benefits.

Merchant. From a technological point, both services have some technological issues and only partly met the expectations of Axfood. Due to a small number of users and transactions, both services have not met retailer's expectations about the economic benefits and a critical mass of users. However, SEQR ensures a lower transaction fee. The value of the introduction of Bart and SEQR for Axfood was the increased attention of mass media and opportunity to get the experience in offering this type of service. However, Bart performed only a payment function, while SEQR met retailer expectations' more completely because of proposed additional services. Finally, SEQR is easier to use compared to Bart.

Consumers. Both services are technologically feasible for consumers and have a zero service cost. However, the major benefits of SEQR are (i) proposed additional services, (ii) expanding service infrastructure, and (iii) ease of use.

To sum up, the SEQR service meets the expectations of the involved stakeholders more completely. McDonald's experience supports this finding. In the Bart case, many stakeholder expectations' were not fulfilled. 


\section{Discussion and conclusions}

We have used the example of two services, Bart and SEQR, to illustrate the expectations of different stakeholders involved in mobile payment services in the Swedish retail industry. In order to be adopted, mobile payment services need to meet expectations of multiple stakeholders. These expectations represent a complex set of factors where all of the factors impact at the same time.

We have proposed that a good technical performance of mobile payment services is important for banks, merchants, and consumers (Proposition 1). The findings show that there are no major problems related to the technical feasibility of mobile payment services. The developed services have met expectations of stakeholders in terms of security, reliability, scalability, ease of service integration in the existing infrastructure, and speed of transactions. These findings confirm Proposition 1 and are in line with the previous study which is focused on merchant adoption of a mobile payment system in Finland (Mallat and Tuunainen, 2008). Additionally, the results of our research propose that mobile payment services best meet the expectations of retailers when there is no need for separate infrastructure and hardware.

Within this research, we have defined relative advantage with the help of dimensions of economic benefits, lower service cost, and added value of a service. Overall, it is possible to conclude that the Bart service did not provide a sufficient relative advantage to stakeholders and a number of stakeholders' expectations were not fulfilled.

Our findings have validated Proposition 2 stating that companies expect to improve their economic performance and to increase profit by introducing mobile payments. In terms of economic benefits, Swedbank could not make use of a new business case that could have potentially become a new source of revenue. In contrary, the independent mobile payment provider, Seamless, tries to take advantage of this new service. The company actively develops networks of retailers and consumers, and increases its share of the payment market. Economic benefits of the mobile payments include an increase in the volume of impulse purchases which leads to an increase in revenues (Mallat and Tuunainen, 2008). However, in both cases retailers' expectation to reduce in-store cash transactions did not happen due to the small number of mobile transactions. Overall, SEQR is moving towards the realisation of mobile payment potential through newly introduced features (loyalty cards and cashback payments). These service features could bring new service customers.

According to Proposition 3, one of the major expectations of retailers and consumers about mobile payment is a lower service cost (van der Heijden, 2002; Karnouskos and Fokus, 2004; Mallat and Tuunainen, 2008; Chen, 2008). During the interviews, it was not disclosed if the Bart service cost was lower than the bank's card transaction fee. However, the service required investment in infrastructure and additional equipment. In turn, Seamless realised that in order to be accepted, the mobile payment service should provide a business case for merchants. SEQR meets expectations of retailers about a zero investment cost in service infrastructure and a lower service cost compared to credit card transaction fees. Both services have met consumer expectations of a zero service cost. These findings are in line with Proposition 3.

Previous studies (Laukkanen and Kiviniemi, 2010; Mallat and Tuunainen, 2008; Plouffe et al., 2000) have highlighted the importance of having added value of a mobile service for merchants and customers (Proposition 4). Indeed, 'the pure convenience and novelty elements' (Plouffe et al., 2000:121) of a new payment service are not enough for service acceptance. A mobile payment service should provide something more than just payment in order to be more attractive than a credit card. In this context, Bart's value for retailing is questionable because the service acted like a credit card on a mobile phone and did not provide any additional service for either the consumers or retailers. This relates to the observation that banks forget to provide 'the compelling reason for a consumer' to use a new payment service on a continuous basis (Plouffe et al., 2000:112). 
The SEQR service provides a different example. This service has a range of services for consumers (such as person-to-person payments, transport ticketing, parking payments, loyalty programmes, and cashback payments) and for retailers (e.g. cashback payment promoting retailers' and products' brands). In addition, retailers decided to introduce the mobile payment service because it could positively affect the company's image and enhance the customer purchasing experience by making the overall process simpler and quicker. These findings are in line with a previous study on merchants' adoption of mobile payments (Mallat and Tuunainen, 2008) and validate Proposition 4.

The empirical findings of previous studies on mobile payments (van der Heijden, 2002; Plouffe et al., 2000; Mallat and Tuunainen, 2008) have highlighted the importance of network externalities and critical mass. Their main effect is interdependence existing between all involved stakeholders when 'critical mass in one area would certainly impact critical mass in another area, and vice versa' (van der Heijden, 2002:438). Thus, merchants expect a critical mass of consumers, consumers expect a wide network of merchants, and mobile payment providers expect to attract both merchants and consumers (Proposition 5).

According to our findings, Bart failed to reach a critical mass of end-users. Indeed, in order to reach a return on investment, banks need a considerable number of customers (Laukkanen and Kiviniemi, 2010). In contrary, Seamless has minimised the impact of network externalities and critical mass on service adoption by retailers. This is achieved by offering a zero investment cost and a lower service price. Indeed, according to Goldenberg et al. (2010), a lower product price tends to minimize the effect of network externalities. Hence, although retailers would like to see more service users and an increase in transaction volumes, an insufficient critical mass of consumers and investment risks do not affect service acceptance. This finding differs with findings by Mallat and Tuunainen (2008:46), which have defined 'a wide user base' as 'a precondition' for merchant adoption. Hence, our Proposition 5 regarding critical mass is only partially supported.

According to previous research (van der Heijden, 2002), ease of use and a user-friendly interface are other important expectations of merchants and consumers on mobile payment services (Proposition 6). Bart is an example of a complicated service. In addition, shop cashiers tended to forget how to accept mobile payment as time passed by. Our finding is in line with a previous study (van der Heijden, 2002). In contrary, SEQR is a user-friendly service and greater meets the expectations of personnel and consumers. Therefore, our Proposition 6 has been validated.

Our overall findings have shown that even a successful mobile payment service still does not meet all the expectations of the main stakeholders. In addition, existing services only partly enhance the purchasing process through making it faster. Mobile payment service providers could take the next step towards providing an opportunity of self-scanning, where consumers scan prices while shopping in the store and could pay just by pressing a button before leaving the store. This is what retailers expect from the enhanced purchasing process.

\subsection{Theoretical implications}

This study provides several theoretical contributions to the existing research on mobile payments and mobile services. First of all, it explores a previously unexplored area concerning stakeholders' expectations by building a research framework based on TAM, diffusion of innovations theory, and network externalities. We have validated the proposed framework of stakeholders' expectations by the executed qualitative research and proved its significance. Hence, the postulated set of analysis factors may be used for further research in the domain of stakeholders' expectations of mobile payments.

Second, our research and proposed research framework contributes to a better understanding of the factors that affect mobile payment service adoption by merchants. Our findings suggest that the more a 
mobile payment service meets the merchants' expectation, the more the merchants are willing to adopt it.

Third, this research is one of only a few which addresses the area of mobile payment service adoption by retailers. We used qualitative research in order to explore this research domain by testing theoretical assumptions in practice.

\subsection{Practical implications}

This study provides important implications and strategic guidelines for practitioners developing mobile payment services. The proposed research framework can be used as a tool which provides a set of criteria that mobile payment services have to meet.

One of the most significant research insights is addressing the strategy of mobile payment providers. These actors need to build networks which include both merchants and consumers in order to succeed in the market. Hence, they should have a keen understanding of the needs and expectations of these two groups of stakeholders and adjust their service accordingly.

Our findings suggest that retailers expect a secure and fast service which requires no additional hardware, helps to increase the number of consumer impulse purchases and to reduce the number of cash transactions, and has a lower transaction fee compared to credit cards. They do not want any additional investment in service infrastructure. They would also like integrated loyalty programmes, an improved company image, and an easy-to-use service.

Service infrastructure and a user-friendly service are very important to consumers. Furthermore, the research findings propose that consumers will not adopt a mobile payment service, which only provides payment functionality. In Sweden, bank cards are the most popular means of payment. In order to be competitive, mobile payment services have to provide added value services.

The empirical evidence shows that banks have had practical problems launching mobile payment services. In our analysed case, the initial idea of the service had the perfect potential to be adopted in the market. However, its practical implementation did not meet the expectations of retailers and consumers. As a result, banks are now excluded from direct service provisioning.

Finally, our investigation into stakeholders' expectations has helped to explain why mobile payment services have not yet been that successful. In order to become a popular payment system, mobile payment services need to meet the expectations of the main stakeholders in the best possible way, and this is a prerequisite for service adoption.

\subsection{Limitations and future research}

The major limitation of this paper is that only several retailers were contacted. This limitation could influence and bias the estimation of common trends and the generalisation of the research results.

Future work should be focused on the analysis of expectations of a larger number of retailers. This would give a more comprehensive picture of stakeholders' expectations of mobile payments. Another possible direction for research would be a quantitative study of stakeholders' expectations. A longitudinal study which would determine whether the mobile payment service actually fulfils stakeholder expectations' over a longer time period could be another research direction.

\section{Acknowledgment}

This research had been performed as a part of Mobimer project, which is funded by wireless@kth. Additionally, funding has been provided by Handelsbanken's Research Foundation. 
The authors would like to thank the representatives of the companies for their valuable input and interviews. The authors are grateful to the two anonymous reviewers and the journal's guest editor Dr. Mohammad Nejad for their comments. In addition, the authors would like to thank the three anonymous reviewers that provided their comments on the initial version of this paper submitted to the International Conference of Mobile Business (ICMB 2014).

\section{References}

Arvidsson, N. (2013), Det kontantlösa samhället-rapport från ett forskningsprojekt. (in Swedish) KTH, Industriell dynamik, Stockholm, TRITA IEO-R 2013:01, ISBN 1100-7982.

Arvidsson, N. (2014), 'Consumer attitudes on mobile payment services - results from a proof of concept test', International Journal of Bank Marketing, Vol. 32 No. 2, pp. 150-170.

$\mathrm{Au}$, Y.A. and Kauffman, R.J. (2008), 'The economics of mobile payments: Understanding stakeholder issues for an emerging financial technology application', Electronic Commerce Research and Applications, Vol. 7 No. 2, pp. 141-164.

Bhattacherjee, A. (2012), Social science research: Principles, methods, and practices. $2^{\text {nd }}$ ed., Global text project.

Chemingui, H. and Ben lallouna, H. (2013), 'Resistance, motivations, trust and intention to use mobile financial services', International Journal of Bank Marketing, Vol. 31 No. 7, pp. 574-592.

Chen, L.-D. (2008), 'A model of consumer acceptance of mobile payment', International Journal of Mobile Communications, Vol. 6 No. 1, pp. 32-52.

Chong, A.Y.L. (2013), 'Mobile commerce usage activities: The role of demographics and motivation variables', Technological Forecasting and Social Change, Vol. 80 No. 7, pp. 1350-1359.

Chwelos, P., Benbasat, I. and Dexter, A.S. (2001), 'Research report: Empirical test of an EDI adoption model', Information Systems Research, Vol. 12 No. 3, pp. 304-321.

Constantiou, I.D., Damsgaard, J. and Knutsen, L. (2006), 'Exploring perceptions and use of mobile services: user differences in an advancing market', International Journal of Mobile Communications, Vol. 4 No. 3, pp. 231-247.

Dahlberg, T., Mallat, N., Ondrus, J. and Zmijewska, A. (2008), 'Past, present and future of mobile payments research: A literature review', Electronic Commerce Research and Applications, Vol. 7 No. 2, pp. 165-181.

Davis, F.D. (1989), 'Perceived usefulness, perceived ease of use and user acceptance of information technology', MIS Quarterly, Vol. 13 No. 3, pp. 319-340.

Davis, F.D., Bagozzi, R.P. and Warshaw P.R. (1989), 'User acceptance of computer technology: A comparison of two theoretical models', Management Science, Vol. 35 No. 8, pp. 982-1003.

Duane, A., O'Reilly, P. and Andreev, P. (2014), 'Realising M-Payments: Modelling consumers' willingness to M-pay using Smart Phones', Behaviour and Information Technology, Vol. 33 No. 4, pp. 318-334.

Eisenhardt, K.M. (1989), 'Building theories from case study research', The Academy of Management Review, Vol. 14 No. 4, pp. 532-550.

Economides, N. (1996), 'The economics of networks', International Journal of Industrial Organization, Vol. 14 No. 6, pp. 673-699.

Frambach, R.T. and Schillewaert, N. (2002), 'Organizational innovation adoption: A multi-level framework of determinants and opportunities for future research', Journal of Business Research, Vol. 55 No. 2, pp. 163-176.

Frolick, M.N. and Chen, L.-D. (2004) 'Assessing m-commerce opportunities', Information Systems Management, Vol. 21 No. 2, pp. 53-61.

Gerrard, P.J. and Cunningham, B. (2003), 'The diffusion of Internet banking among Singapore consumers', International Journal of Bank Marketing, Vol. 21 No. 1, pp. 16-28.

Goldenberg, J., Libai, B. and Muller, E. (2010), 'The chilling effects of network externalities', International Journal of Research in Marketing, Vol. 27 No. 1, pp. 4-15. 
Goeke, L. and Pousttchi K. (2010), 'A scenario-based analysis of mobile payment acceptance', in The Ninth International Conference on Mobile Business / Ninth Global Mobility Roundtable proceedings, 2010.

Harrison, T.S., Onyia, O.P. and Tagg, S.K. (2014), 'Towards a universal model of internet banking adoption: initial conceptualization', International Journal of Bank Marketing, Vol. 32 No. 7, pp. 647-687.

Hsu, C.-L., Wang, C.-F. and Lin, J.C.-C. (2011), 'Investigating customer adoption behaviours in mobile financial services', International Journal of Mobile Communication, Vol. 9 No. 5, pp. 477494.

Johnson, M. (2009), 'Barriers to innovation adoption: A study of e-markets', Industrial Management and Data Systems, Vol. 110 No. 2, pp. 157-174.

Johnson, M. (2010), 'Industrial e-market adoption: an exploratory study of organizational change issues', International Journal of Business Innovation and Research, Vol. 4 No 6, pp. 535-559.

Karnouskos, S. and Fokus, F. (2004), 'Mobile payment: A journey through existing procedures and standardization initiatives', IEEE Communications, Vol. 6 No. 4, pp. 44-66.

Kauffman, R.J., McAndrews, J. and Wang, Y.-M. (2000), 'Opening the 'black box' network externalities in network adoption', Information Systems Research, Vol. 11 No. 1, pp. 61-82.

Kim, C., Mirusmonov, M. and Lee, I. (2010a), 'An empirical examination of factors influencing the intention to use mobile payment', Computers in Human Behavior, Vol. 26 No. 3, pp. 310-322.

Kim, C., Tao, W., Shin, W. and Kim, K.S. (2010b), 'An empirical study of customers' perceptions of security and trust in e-payment systems', Electronic Commerce Research and Applications, Vol. 9 No. 1, pp. 310-322.

Klein, H.K. and Myers, M.D. (1999), 'A set of principles for conducting and evaluating interpretive field studies in information systems', MIS Quarterly, Vol. 23 No. 1, pp. 67-93.

Lapierre, J. and Denier, A. (2005), 'ICT adoption and moderating effects of institutional factors on salesperson's communication effectiveness: a contingency study in high-tech industries', Technovation, Vol. 25 No. 8, pp. 909-927.

Laukkanen, T. and Kiviniemi, V. (2010), 'The role of information in mobile banking resistance', International Journal of Bank Marketing, Vol. 28 No. 5, pp. 372-388.

Luo, X., Li, H., Zhang, J. and Shim, J.P. (2010), 'Examining multi-dimensional trust and multi-faceted risk in initial acceptance of emerging technologies: An empirical study of mobile banking services', Journal of Decision Support Systems, Vol. 49 No. 2, pp. 222-234.

Mahler, A. and Rogers, E.M. (1999), 'The diffusion of interactive communication innovations and the critical mass: The adoption of telecommunications services by German banks', Telecommunications policy, Vol. 23 No. 10, pp. 719-740.

Mallat, N. (2007), 'Exploring consumer adoption of mobile payments - A qualitative study', Journal of Strategic Information Systems, Vol. 16 No. 4, pp. 413-432.

Mallat, N., Rossi, M., Tuunainen, V.K. and Öörni, A. (2009), 'The impact of use context on mobile services acceptance: The case of mobile ticketing', Information and Management, Vol. 46, pp. 190195.

Mallat, N. and Tuunainen, V.K. (2008), 'Exploring merchant adoption of mobile payment systems: An empirical study', e-Service Journal, Vol. 6 No. 2, Winter 2008, pp. 24-57.

Markendahl, J. (2013), 'Change of market structure for mobile payment services in Sweden - The case of SMS tickets', in: The 12th International Conference on Mobile Business (ICMB 2013), Berlin, Germany, June 10-13, 2013.

Oliveira, T. and Martins, M.F. (2010), 'Understanding e-business adoption across industries in European countries', Industrial Management and Data Systems, Vol. 110 No. 9, pp. 1337-1354.

Ondrus, J. and Lyytinen, K. (2011), 'Mobile payments market: Towards another clash of the Titans?', in The 10th International Conference on Mobile Business (ICMB 2011) proceedings of the conference in Como, Italy, 2011, IEEE, pp. 166-172. 
Ondrus, J., Lyytinen, K. and Pigneur, Y. (2009), 'Why mobile payment fail? Towards a dynamic and multi-perspective explanation', in The 42nd Hawaii International Conference on System Science (HICSS'09) proceedings of the conference in Hawaii, USA, 2009, IEEE, pp. 1-10.

Orlikowski, W.J. and Baroudi, J.J. (1991), 'Studying information technology in organizations: research approaches and assumptions', Information Systems Research, Vol. 2 No. 1, pp. 1-28.

Plouffe, C.R., Vandenbosch, M. and Hulland, J. (2000), 'Why smart cards have failed: Looking to consumer and merchant reactions to a new payment technology', International Journal of Bank Marketing, Vol. 18 No. 3, pp. 112-123.

Püschel, J., Mazzon, J.A. and Hernandez, J.M.C. (2010), 'Mobile banking: proposition of an integrated adoption intention framework', International Journal of Bank Marketing, Vol. 28 No. 5, pp. 389-409.

Rogers, E.M. (2003), Diffusion of innovations. $5^{\text {th }}$ ed., London: Simon \& Schuster.

Schierz, P.G., Schilke, O. and Wirtz, B.W. (2010), 'Understanding consumer acceptance of mobile payment services: An empirical research', Journal of Electronic Commerce Research and Applications, Vol. 9 No. 3, pp. 209-216.

Shin, D. (2009), 'Towards an understanding of the consumer acceptance of mobile wallet', Computers in Human Behavior, Vol. 25 No. 6, pp. 1343-1354.

Song, M., Parry, M.E. and Kawakami, T. (2009), 'Incorporating network externalities into the technology acceptance model', Journal of Product Innovation Management, Vol. 26 No. 3, pp. 291-307.

Srinivasan, R., Lilien, G.L. and Rangaswamy, A. (2004), 'First in, first out? The effects of network externalities on pioneer survival', Journal of Marketing, Vol. 68 No. 1, pp. 41-58.

Szmigin, I. and Bourne, H. (1999), 'Electronic cash: a qualitative assessment of its adoption', International Journal of Bank Marketing, Vol. 17 No. 4, pp. 192-202.

van der Heijden, H. (2002), 'Factors affecting the successful introduction of mobile payment systems', in: The 15th Bled Electronic Commerce Conference, Bled, Slovenia, June 17-19, 2002.

van Hove, L. (1999), 'Electronic money and the network externalities theory: lessons for real life', Netnomics, Vol. 1, pp. 137-171.

Venkatesh, V., Morris, M., Davis, G.B. and Davis, F.D. (2003), 'User acceptance of information technology: Towards a unified view', MIS Quarterly, Vol. 27 No. 3, pp. 425-478.

Venkatesh, V., Thong, J.Y.L. and Xu, X. (2012), 'Consumer acceptance and use of information technology: Extending the unified theory of acceptance and use of technology', MIS Quarterly, Vol. 36 No. 1, pp. 157-178.

Yang, S., Lu, Y., Gupta, S., Cao, Y. and Zhang, R. (2012), 'Mobile payment service adoption across time: An empirical study of the effects of behavioural beliefs, social influences, and personal traits', Computers in Human Behavior, Vol. 27 No. 1, pp. 129-142.

Yousafzai, S. and Yani-de-Soriano, M. (2012), 'Understanding customer-specific factors underpinning internet banking adoption", International Journal of Bank Marketing, Vol. 30 No. 1, pp. 60-81.

Zhou, T., Lu, Y. and Wang, B. (2010), 'Integrating TTF and UTAUT to explain mobile banking user adoption', Computers in Human Behavior, Vol. 26 No. 4, pp. 760-767.

\section{Web pages}

Axfood, (2012), 'Mobile payment with Bart to Willys and Hemköp stores', Press release, 16

November, 2012, available at: http://www.axfood.se/Documents/Pdf/PressReleases/en/719505.pdf (accessed 29 June 2013).

Barbuta, I., Dobrean, S., Gaza, M., Mihaila, M., and Screpnic, A. (2012), 'Mobile payments guide 2012: Insights in the worldwide mobile financial service market', Released by The Paypers BV, March, 2012, available at: http://ibfsinc.com/uploads/Mobile_Payments_Market_Guide_2012.pdf (accessed 29 March 2015). 
Capgemini and RBS (2014), 'World payments report', available at: https://www.worldpaymentsreport.com/ (accessed 6 March 2015).

Clark, S. (2014), 'O2 UK to shutdown mobile wallet service', NFC World, 9 January, available at: http://www.nfcworld.com/2014/01/09/327453/o2-uk-shut-mobile-wallet-service/ (accessed 30 March 2015).

Ericsson (2014), 'Europe: Ericsson mobility report appendix', June, 2014, available at: http://www.ericsson.com/res/docs/2014/emr-june2014-regional-appendices-europe.pdf (accessed 30 March 2015).

Seamless, (2012), 'Seamless launched easy transfer to all bank accounts in Sweden', Press release, 28 August, 2012, available at: http://mb.cision.com/Main/3006/9297088/39604.pdf (accessed 23 March 2013).

Seamless, (2013), 'Seamless enters into agreement with McDonald's in Sweden', Press release, 5 March 2013, available at: http://ir.seamless.se/releasedetail.cfm?ReleaseID=745202 (accessed 20 October 2013).

SvD, (2014), 'Swedbank lägger ned betallösningen Bart', (in Swedish) svd.se, 21 January, 2014, available at: http://www.svd.se/naringsliv/swedbank-lagger-ned-betallosningen-bart 8913772.svd (accessed 25 January 2014).

Telia, (2012), 'Information om villkorsändring och uppsägning av Telia Mobil plånbok', (in Swedish), Press release, available at: https://www.telia.se/docs/villkor/Uppsagning-telia-mobil-planbok.pdf (accessed 29 March 2015). 


\section{Appendix A: Questionnaire}

\section{Organisation strategy}

1. How could a company's overall business strategy be characterised?

2. Is it open to adopting new products or services?

\section{Characteristics of mobile payment solution}

1. When making a decision about the deployment of a mobile payment, what was seen as the potential benefits?

2. What kind of relative advantage was expected of the deployment of a mobile payment service?

3. Does the deployment of a mobile payment solution meet the company's expectations?

4. How does the deployment of a mobile payment correspond to the values of your company?

5 . How does the deployment of a mobile payment correspond to the needs of your company?

6. Is a mobile payment solution used for payment in the physical shops?

6a. If yes, were any problems encountered when personnel had to learn and start using the mobile payment solution?

7. What is the economic factor of mobile payment deployment?

8. Is the option to pay with a mobile payment solution visible to the customers? How?

9. What are the results of using a mobile payment solution in shops? What is its advantage?

10. Does the company feel any uncertainty about the mobile payment solution?

\section{Marketing efforts of the mobile payment provider}

1. Who initiated the idea of deployment a mobile payment solution at your company?

2. What were the main factors behind selecting X company as a mobile payment provider?

3. How did the mobile payment provider communicate about mobile payment solution?

4. Were any risk reduction measures proposed by the mobile payment provider?

\section{Social networks}

1. For your company, how important was the use of different social networks in order to get additional information about the mobile payment solution?

2. Did it have any impact on the final decision to select the mobile payment provider?

\section{Influence of market factors}

1. Was the 'chicken and egg' dilemma an important problem when considering the deployment of the mobile payment solution?

2. Was the decision to deploy a mobile payment affected by similar decisions from competitors? 